\title{
Probiotics study with Streptococcus salivarius and its ability to produce bacteriocins and adherence to KB cells
}

\author{
Estudo de probióticos Streptococcus salivarius e sua habilidade de produzir \\ bacteriocinas e aderência à células KB
}

\author{
Vera FANTINATO ${ }^{a *}$ (D), Heloísa Ramalho CAMARGO ${ }^{b}$ (D), Ana Lúcia Orlandinni Pilleggi de SOUSAc (D) \\ aUNESP - Universidade Estadual Paulista, Instituto de Ciência e Tecnologia, São José dos Campos, SP, Brasil \\ ${ }^{\text {b} C H T ~ Q u i m i p e l ~ B r a z i l ~ Q u i ́ m i c a ~ L t d a, ~ T e ́ c n i c a ~ d e ~ L a b o r a t o ́ r i o, ~ B r a g a n c ̧ a ~ P a u l i s t a, ~ S P, ~ B r a s i l ~}$ \\ 'Duas Rodas, Centro de Inovação, Jaraguá do Sul, SC, Brasil
}

\begin{abstract}
How to cite: Fantinato V, Camargo HR, Sousa ALOP. Probiotics study with Streptococcus salivarius and its ability to produce bacteriocins and adherence to KB cells. Rev Odontol UNESP. 2019;48: e20190029. https://doi.org/10.1590/18072577.02919
\end{abstract}

\begin{abstract}
Resumo
Introdução: Streptococcus salivarius é uma espécie dominante na cavidade bucal e tem sido indicada como um ótimo candidato para uso como probiótico. Visto que a espécie Streptococcus salivarius é capaz de produzir bacteriocinas contra Streptococcus pyogenes, desenvolveu-se interesse no uso desse microrganismo como probiótico, para evitar amigdalites causadas por Streptococcus pyogenes. Objetivo: A pesquisa em questão tem o objetivo de selecionar cepas de Streptococcus salivarius para seu uso potencial como probióticos na cavidade bucal, ou seja, produção de bacteriocinas contra Streptococcus pyogenes e habilidade de aderência à células KB. Material e método: Coletou-se material de língua de 45 estudantes e semeou-se em placas de ágar Mitis Salivarius. As amostras foram testadas para verificar a produção de substâncias semelhantes à bacteriocina (BLIS) contra S. pyogenes, bioquimicamente e através de PCR para identificação de S. salivarius. As melhores cepas foram testadas quanto aderência à células KB. Resumidamente, as cepas de $S$. salivarius foram cultivadas em caldo, lavadas e suspensas à correspondência de $10^{8} \mathrm{cels} / \mathrm{ml}$. As células KB foram inoculadas em placas, lavadas e incubadas com as bactérias, para adesão. Estas foram lavadas para lise das células KB e liberação das bactérias para determinação de UFC. Resultado: 0 teste de bacteriocina, mostrou que 133 cepas apresentaram atividade inibitória contra Streptococcus pyogenes. As cepas testadas para aderência à células $\mathrm{KB}$, apresentaram diferentes perfis e somente três com alta capacidade de adesão. Conclusão: A seleção de cepas de Streptococcus salivarius com alta atividade inibitória contra Streptococcus pyogenes, bem como aderência a células KB, pode nos levar ao próximo passo, ou seja, o uso das melhores cepas para o estudo de colonização in vivo.
\end{abstract}

Descritores: Probióticos; Streptococcus salivarius; Streptococcus pyogenes; antagonismo; bacteriocina; aderência a células KB.

\begin{abstract}
Introduction: Streptococcus salivarius is a dominant oral species and the best suitable candidate for probiotic of the oral cavity. Since Streptococcus salivarius is able to produce bacteriocins against Streptococcus pyogenes interest has been focused on the use of it as a probiotic to avoid sore throats by Streptococcus pyogenes. Objective: This study is for selecting Streptococcus salivarius strains for potential use as probiotics for the oral mucosa, that is, production of bacteriocin against Streptococcus pyogenes and the ability to bind to KB cells. Material and method: Tongue material from 45 students was collected and seeded on Mitis Salivarius Agar plaques. The strains were tested by the production of bacteriocin-like substances (BLIS) against S. pyogenes, biochemically and PCR for identification of S. salivarius. The best strains were tested for adherence to KB cells. Briefly, S. salivarius strains were cultured in broth, washed and suspended at $10^{8}$ cells $/ \mathrm{ml}$. KB cells were inoculated into plaques, washed and incubated with the
\end{abstract}


bacteria, for adhesion. These were washed for lysis of the KB cells and release bacteria for determination of CFU. Result: The bacteriocin test showed that 133 strains presented inhibition of S. pyogenes. The samples tested for adhesion to KB cells, presented different profiles and only three strains presenting high adhesion capacity. Conclusion: The selection of strains of Streptococcus salivarius with high inhibitory activity against Streptococcus pyogenes, as well as adherence to KB cells leads us to the next future step, that is, to use the best strains for in vivo colonization tests

Descriptors: Probiotics; Streptococcus salivarius; Streptococcus pyogenes; antagonism; bacteriocin; adhesion KB cell.

\section{INTRODUCTION}

The oral cavity is highly selective for microorganisms, especially during the first days of life. Despite the widespread bacteria in the environment, the mouth of the newborn baby allows the colonization of just a few species of microorganisms. Streptococcus salivarius is one of the most important pioneer colonizers of neonatal oral mucosa surfaces and a predominant component of the human adult oral microbiota ${ }^{1,2}$. Although its presence is associated with protection against pathogenic bacteria, information about receptors on bacterial and host surfaces is still being researched.

Some strains of Streptococcus salivarius are able to produce bacteriocins that inhibit the growth of Streptococcus pyogenes in vitro. The term bacteriocin-like inhibitory substance (BLIS) ${ }^{3,4}$ is used to describe bacterial products that have inhibitory effects like those of bacteriocins, prior to the isolation and characterization of the active agent. In a previous study, we have reported that $98 \%$ of the children who had never developed sore throat presented Streptococcus salivarius BLIS positive strains in their tongues ${ }^{5}$. The presence of this bacteria in the mouth can prevent pharyngeal infections, especially in school-aged children ${ }^{6}$. The relative ability of bacteria to become attached to oral surfaces influences the extent to which they colonize. Streptococcus salivarius has been extensively studied for the prevention of tonsillitis; however almost $100 \%$ were performed with the $S$. salivarius K12 strain, the only one in the market. We think there may be more possibilities with other strains and this is why we are conducting this research. However, one of the first phases of studies in this sense would be the evaluation of strains that have better ability to adhere to the buccal mucosa, which are rarely found in the literature. The present study investigated the production of inhibitory substances by $S$. salivarius isolated from the tongue of healthy children and the ability of these strains to adhere to KB cells.

\section{MATERIAL AND METHOD}

The Research Ethics Committee from the Israeli Hospital Albert Einstein, authorized the collection of tongue material from students, with attention to the fact that the research subject has the freedom to withdraw his participation in any phase of the research. The tongue of 45 students (9-14 years old) were swabbed under the informed consent and the samples immediately inoculated on Mitis Salivarius Agar (Difco) plates and incubated at $37^{\circ} \mathrm{C} / 24 \mathrm{~h} / \mathrm{CO}_{2}$. An average between 20 and 25 colonies resembling $S$. salivarius from each plate were cultured in Todd-Hewitt broth (Difco). This number of colonies has been stablished as an ideal indicative sample of the presence of bacteriocin-producing strains ${ }^{5}$. The objective was to obtain as many colonies as possible that indicated that the volunteer is a carrier of bacteriocin positive strains.

All 1050 isolates were tested for BLIS production using a simultaneous antagonism test 3,4 against nine different S. pyogenes strains: ATCC 19615, ATCC 1095, ATCC S1183, a clinical isolate from otitis (OT1), and five others from sore throats (ST1, ST2, ST3, ST4, ST5). The test conducted to verify the production of bacteriocins was the simultaneous antagonism test and always performed in triplicate. S. salivarius CDC SS 262 strain was used as negative control for 
antagonism against $S$. pyogenes. The $S$. pyogenes (indicator strains) were swabbed on Columbia Blood Agar supplemented with sheep blood (5\%, vol/vol) in a $5 \% \mathrm{CO}_{2}$-air atmosphere at $37^{\circ} \mathrm{C} / 24 \mathrm{~h}$. Samples of S. salivarius to be tested as bacteriocin-producing were seeded on blood agar and incubated at $37^{\circ} \mathrm{C} / 24 \mathrm{~h}$. With sterile toothpicks, these cultures were collected and punctured 3 times in the center of the plates sown with the $S$. pyogenes indicators.

After incubation at $37^{\circ} \mathrm{C} / 24 \mathrm{~h}$, reduced growth of indicator strains in the vicinity of the area punctured with the producer strain provided evidence of inhibitor production.

We obtained 133 strains with clear evidence of inhibition against the nine strains of S. pyogenes tested. Of those, 13 presented the strongest antagonistic action and were selected to be tested biochemically ${ }^{7}$ and by PCR ${ }^{8}$ to identify $S$. salivarius. PCR primers specific for $S$. salivarius, Ssa442F (5'-AAC GTT GAC CTT ACG CTA GC-3') and Ssa2712R (5'-GAT TCT GTC AAA GAA GCC AC-3') were used to amplify a 2271 bp fragment from dextranase (dex) gene. Isolates were prepared for PCR by pelleting $3 \mathrm{ml}$ of bacteria grown in BHI broth, subsequently suspended in $1 \mathrm{ml}$ of sterile MilliQ water. $5 \mu \mathrm{l}$ aliquots of the cell suspension were used in a $50 \mu \mathrm{l}$ reaction containing Reaction Buffer Biotools $1 \mathrm{x}$ with $2 \mathrm{mM} \mathrm{MgCl} 2$ (Madrid, Spain), $1 \mu \mathrm{M}$ of each primer (Invitrogen, Carlsbad, CA, USA), $2 \mathrm{mM}$ dNTPs mix (Invitrogen) and 2,0 U of Taq polymerase (Invitrogen). The amplification reaction was performed in an Eppendorf Mastercycler gradient thermal cycler (Eppendorf, Hamburg, Germany) as described by Igarashi et $\mathrm{al}^{8}$. (2001) as it follows: $95^{\circ} \mathrm{C}$ for $10 \mathrm{~min}$ followed by 26 cycles of denaturation at $94^{\circ} \mathrm{C}$ for $1 \mathrm{~min}$, annealing at $55^{\circ} \mathrm{C}$ for $1 \mathrm{~min}$ and extension at $72^{\circ} \mathrm{C}$ for $1 \mathrm{~min}$. The last cycle comprised denaturation at $94^{\circ} \mathrm{C}$ for $1 \mathrm{~min}$, annealing at $55^{\circ} \mathrm{C}$ for $1 \mathrm{~min}$ and final extension step at $72^{\circ} \mathrm{C}$ for $5 \mathrm{~min}$. The PCR fragments were subjected to electrophoresis on 1.5\% agarose gel in TAE buffer $1 \mathrm{x}$ and stained with ethidium bromide.

- Adhesion Assay. This test was also performed in triplicate. The 13 strains with strong activity against $S$. pyogenes and identified as S. salivarius were cultured on Todd-Hewitt Broth at $37^{\circ} \mathrm{C}$ in $5 \% \mathrm{CO}_{2}$ for four hours until rid log growth phase. Bacteria were then washed in PBS and suspended to corresponding to $10^{8}$ cells $/ \mathrm{ml}$. KB cells, derived from an oral epidermoid carcinoma, were inoculated in 24-well cultures plates and cultivated ${ }^{9,10}$ in modified Dulbeccos Eagle Medium (DMEM) (Sigma Chemical Co, St Louis, EUA) supplemented with $1 \%$ of antibiotic solution $[100 \mathrm{mg} / \mathrm{mL}$ of penicillin (ICN Biomedicals, Ohio, EUA) and streptomycin (Calbiochem, Darmstadt, Germany)], plus 10\% fetal bovine serum (Cultilab, Campinas, Brazil).

At confluence the cells were washed three times with sterile PBS and $1000 \mu \mathrm{L}$ of DMEM (without antibiotic) containing $10^{8}$ bacteria and were transferred to each well. The plates were incubated at $37^{\circ} \mathrm{C}$ in $5 \% \mathrm{CO}_{2}$ for 90 min to allow bacterial adhesion to $\mathrm{KB}$ cells. After incubation, the medium and cells were washed three times with $\mathrm{PBS}$ incubated at $37^{\circ} \mathrm{C}$ in $\mathrm{CO}_{2}$ for $20 \mathrm{~min}$ for lysing the KB cells and to liberate the adhered bacteria. The cell suspensions were submitted to serial dilutions and plated on Mitis Salivarius Agar. CFU of adherent bacteria were calculated.

\section{RESULT}

1050 isolates were obtained from the tongue of students which were tested for the production of bacteriocin-like substances, using the simultaneous antagonism test. This showed that amongst the 45 volunteers, 24 presented strains with inhibitory activity against at least one of the nine Streptococcus salivarius tested. These strains differed in their spectra of inhibition (Figure 1). 


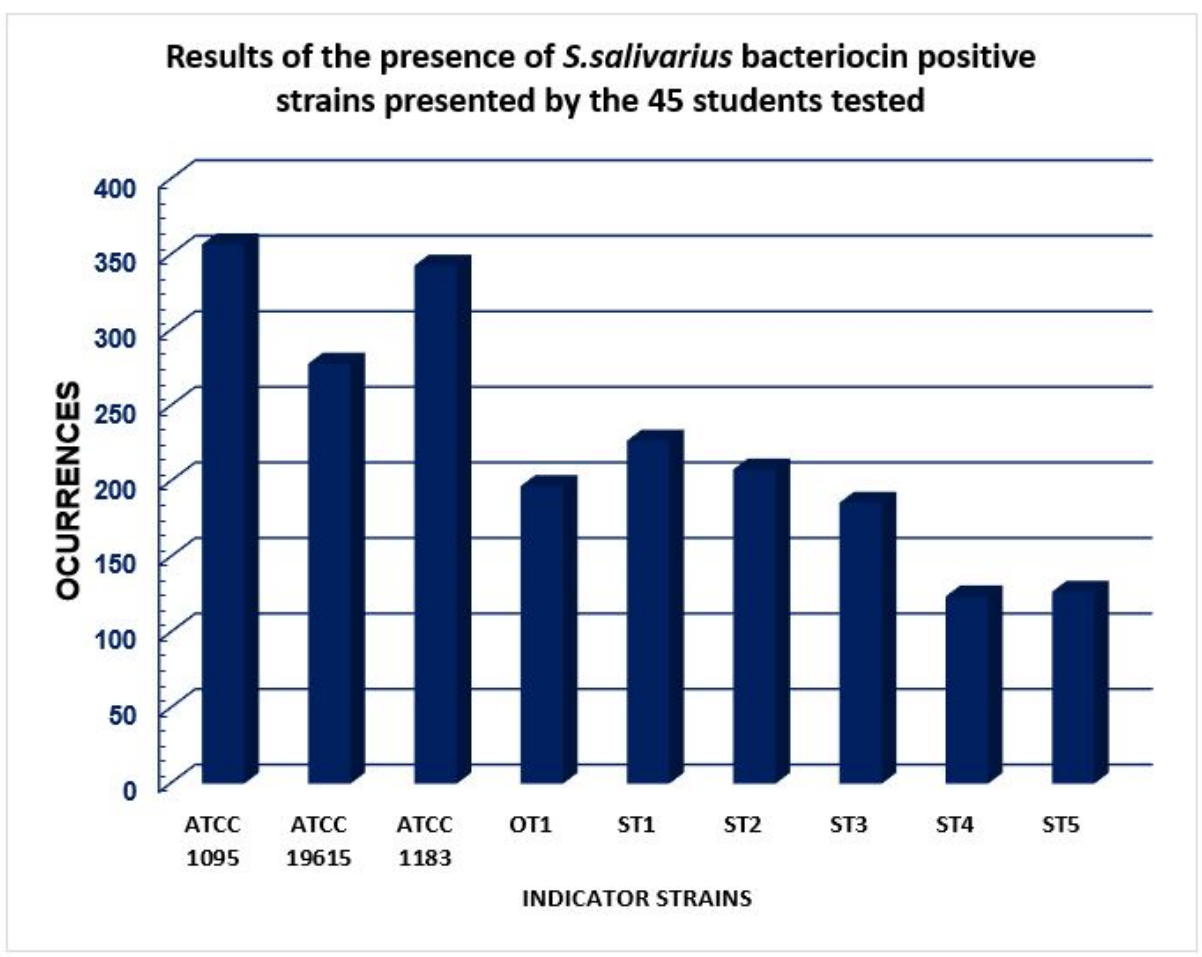

Figure 1. Number of $S$. salivarius strains with bacteriocinogenic activity against the nine strains of S. pyogenes used as indicators.

Among the positive strains to simultaneous antagonism, the ones who showed the strongest activity against all nine GAS were selected for the $S$. salivarius PCR assay, biochemical identification, and adherence tests. The 13 strains that showed the strongest antagonism were also identified as $S$. salivarius by PCR, using specific primers. The four strains VF1, VF2, VF3 and VF4, that tested negative for PCR were isolated from the same volunteer and presented the same profile when tested for antagonistic activity, showing strong inhibition against the nine GAS tested strains. This profile for the simultaneous antagonism was the same presented by the other positive strains for PCR. All 13 strains were biochemically identified as S. salivarius, including the four negative strains for PCR.

Oral streptococci are primarily screened by its colony morphology on Mitis Salivarius Agar plates. The next procedure for identification requires biochemical, immunological and genetic tests. The time and skill to obtain those results have lead the researchers to develop tests using the Polymerase Chain Reaction to satisfy the specificity and sensitivity needs and to reduce the time of lab technician. Igarashi et al. ${ }^{8}$ have used a PCR test targeting dextranase (dex) gene, which is an enzyme hydrolyzing glucans by $S$. mutans. We followed the method established by Igarashi et al. ${ }^{8}$, using a PCR primer on the basis of the nucleotide sequence of dex of $S$. salivarius. This protocol was highly specific for detection and identification of $S$. salivarius strains, since dextranase is widely distributed among oral isolates of S. salivarius (Figure 2). 


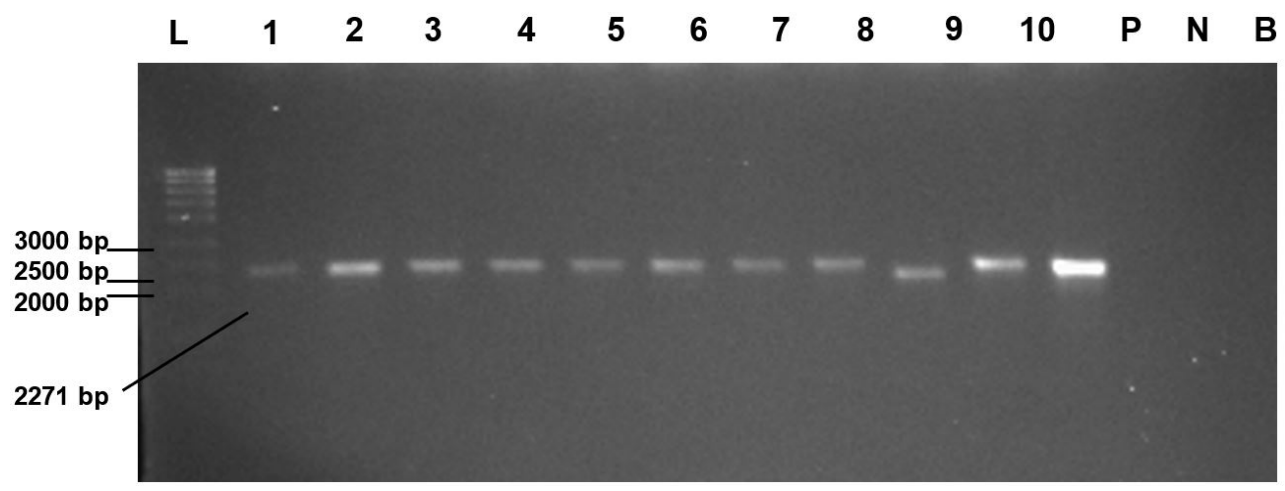

Figure 2. Representative results of some bacterial isolates tested by PCR for dextranase gene. Gene fragment (2271bp) amplified with the Ssa442F and Ssa2712R primer pair and analyzed by ethidium bromide-agarose gel (1,5\% in TAE buffer) electrophoresis. Lanes: L- Mass Ruler High Range Ladder Fermentas (Vilnius, Lithuania) and isolates 1 (4A), 2 (5B), 3 (RA2), 4 (RA4), 5 (RA7), 6 (RA9), 7 (RA10), 8 (12), 9 (ALGS4), 10 (VF13), P (positive control-VF33), N (negative control), B (Blank PCR).

The results achieved enabled us to confirm that data, because we were able to identify nine strains of $S$. salivarius rapidly and precisely. But we could also see that there was a disagreement between the PCR and biochemical tests in four of the strains (Figure 3). To support the results of the biochemical tests of the four negative strains to PCR we believe that the antagonism against $S$. pyogenes would be a strong evidence ${ }^{3}$ of $S$. salivarius, which would align with biochemical methods ${ }^{6}$.

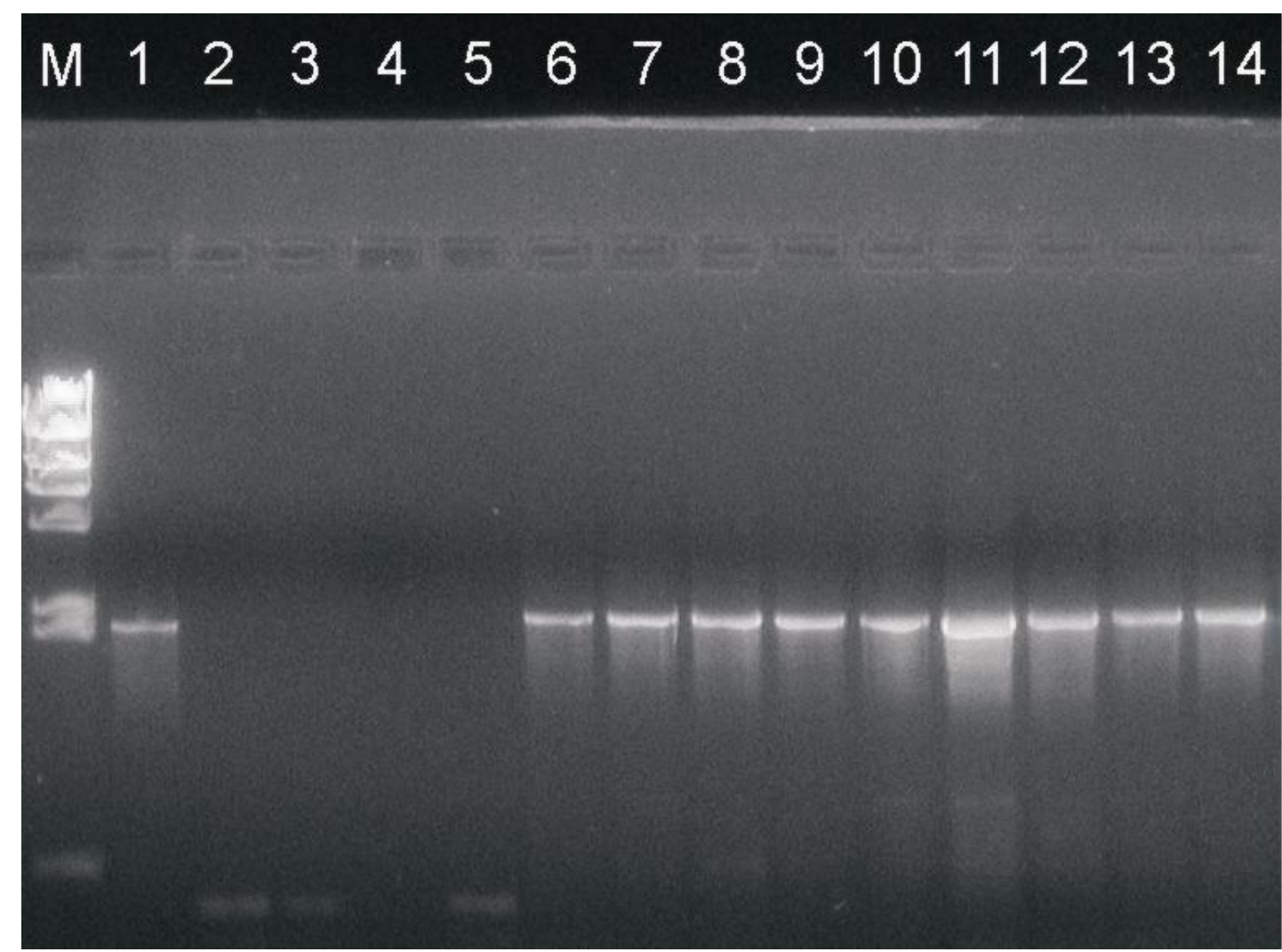

Figure 3. Representative results of PCR products electrophoresis on tongue collected strains. Lanes:

M- molecule marker $1 \mathrm{~Kb}$ plus Invitrogen; 1 - S. salivarius CDC SS 262; 2-VF1; 3-VF2; 4-VF3; 5-VF4; 6-VF7a; 7-VF10; 8-VF11, 9-VF14; 10-VF16; 11-VF19; 12-VF22; 13-VF32a; 14-VF33. 
The capability of the 13 selected bacteriocin positive strains and one negative control strain to adhere $\mathrm{KB}$ cells was tested to evaluate the profile of each strain and test subject, from the tested strains three showed no adhesion to KB cells, therefore were excluded from our selection process. The strains tested positive for adherence are shown in Figure 4, with the results showing different profiles: strains with high (VF3, VF10, VF11) and strains with low (VF7a, VF16, VF19, VF33) adherence ability.

Results of S.salivarius strains adhesion on KB cells

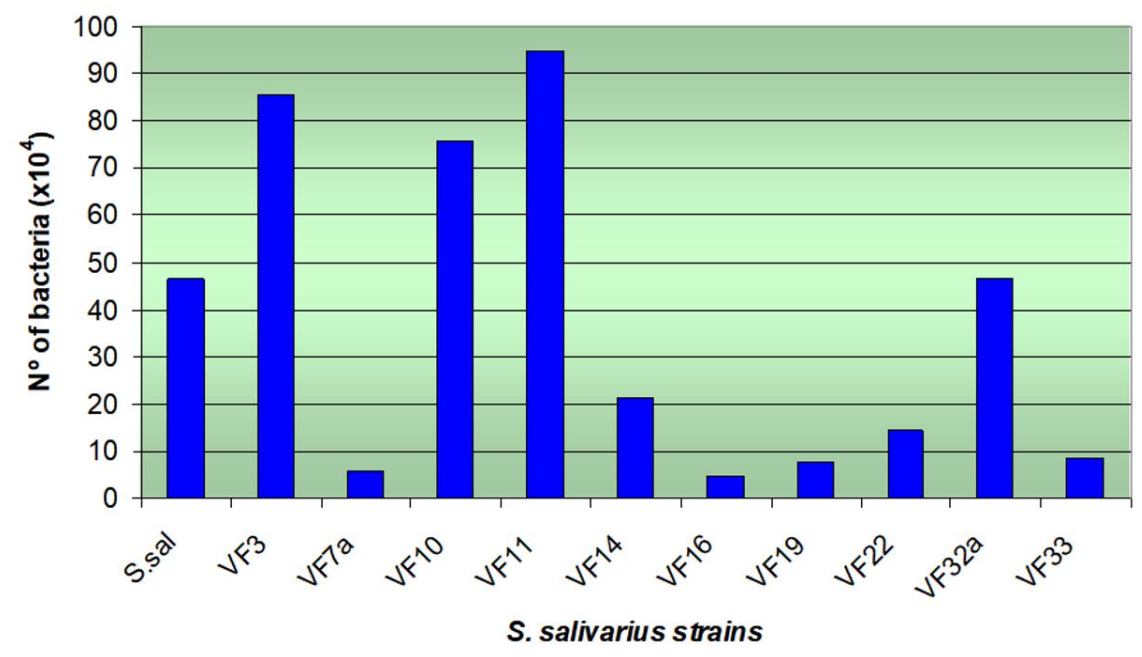

Figure 4. Results of S. salivarius strains adhesion on KB cells.

\section{DISCUSSION}

Our results showed that $53.3 \%$ of the tested individuals presented inhibitory strains against GAS. Fantinato et al ${ }^{5}$ verified that within 54 children that developed purulent recurrent tonsillitis, only $54 \%$ had bacteriocin positive (bac+) S. salivarius against GAS, contrasting with another group of 50 children that never developed the infection, from which $98 \%$ had bac+ strains. This suggests that there is a significative relation between the presence of bac+ strains against GAS and the absence of tonsillitis or pharyngitis.

Regarding the issue of cells adhesion, it is observed that most adherence studies are performed on gram-negative intestinal pathogens. In relation to oral bacteria, similarly, the adherence phenomena have been studied in pathogenic microorganisms. Many of these studies use the KB cells derived from an oral epidermoid carcinoma, which involves continuous cellular lineage, and still retains much of the original fabric characteristics ${ }^{9,10}$.

Some researches ${ }^{10-12}$ studied oral pathogens and virulence factors, and the capacity to adhere to and invade epithelial cells. Since the tests of commensal oral bacteria are practically non-existent, we follow the pathogen adherence patterns, since the cells used for this, also contains antigens of originally healthy cells.

Thinking about adherence and bacteriocin production, could we think that S. salivarius strains producing bacteriocin are particularly well adapted to colonize the mouth and perhaps nasopharynx? From the evolutionary point of view, this characteristic as well as the ability to adhere to epithelial cells, favors bacterial natural selection. We wondered if these two profiles had something in common. If we want to colonize the mouth with probiotics to improve health with BLIS S. salivarius strains as is our final goal, we consider necessary to colonize it with strains with high ability to adhere to epithelial cells. This helps understanding why S. salivarius seem so well adapted to their environment being this one of the most important abilities to reproduce and 
survive. The distinct rates of survival and replication are the results of selection that alters the frequencies of genotypes in a population. This natural selection can be improved by artificial selection, when men introduce his study effort to avoid diseases. There is more and more data to suggest that the acquisition of the oral microbial may be more active than until now recognized ${ }^{12-14}$.

This is the main reason for this study, that is, to obtain the best strains of $S$. salivarius bacteriocin positive and with high capacity of adhesion to the oral cells, for future studies of colonization and for the prevention or treatment of sore throats caused by $S$. pyogenes.

To reinforce the value of using bacteria for the treatment of some infectious diseases, it is interesting to read the article by Florey ${ }^{15}$ published in 1946, the pioneer in the application of replacement therapy where dozens of articles are cited where a non-virulent microorganism is applied directly to an organ to successfully treat an infection. Nowadays is also important the article by Wescomb et al. ${ }^{16}$, which proposes bacteriocin-producing Streptococcus salivarius as a model of oral probiotics. They accomplished significant clinical healing.

Our results showed that each $S$. salivarius strain had different adherence ability. This data is relevant concerning future mouth colonization experiments, thus strains VF3, VF10 and VF11 should be chosen. If we are to be doing the identification just by the PCR method, the VF3 strain would be discharged although it was appointed as second in ability to adhere to KB cells.

Although PCR sensitivity and specificity are excellent advantages, the technique does have some limitations. Among 13 strains of S. salivarius tested, four of them were not identified by the method using dex homologous primers target. Using colonial characteristics, biochemical tests ${ }^{7}$ and fingerprint $\mathrm{t}^{1,2}$ we can get a good identification.

Some authors ${ }^{3,4}$ showed that the property of $S$. pyogenes inhibition is very common among $S$. salivarius strains, but very rare in other oral streptococci and indicates that $S$. salivarius could prevent sore throat caused by $S$. pyogenes if it is used as a probiotic. S. salivarius with the capacity to inhibit GAS, should be used for introduction into the normal mouth flora as a protection against recurrent sore throats. To compete with the mouth bacteria, S. salivarius strains to be introduced as part of the resident microflora should have a strong ability of adherence to epithelial cells. The ability and the factors involved in adherence to oral surfaces should be studied in parallel to antagonism. These isolates exhibiting higher adhesive ability would probably be more capable of colonizing the oral cavity than poorer adhesive isolate.

In the last 10 years, the strain S.salivarius $\mathrm{K} 12$ in the form of losanges, has been intensively studied demonstrating its capacity as a probiotic in the prevention of tonsillitis caused by S. pyogenes ${ }^{17-19}$. Those K12 losanges produced to be used in the prevention and treatment of tonsillitis, has been tested by several authors, always with proven success ${ }^{20}$. Thus, we propose to find more strains of S. salivarius, with the same objective, however, using different vehicles. To do so, we need to evaluate the steps of isolation, characterization of antagonism against $S$. pyogenes, adhesion capacity, toxigenicity and then, other vehicles to introduce this microorganism into its natural habitat, the oral cavity, for further in vivo tests.

\section{CONCLUSION}

The results showed different bacteriocin production profiles as well as to KB cell binding. This shows that it is possible the selection of new strains of S. salivarius with high inhibitory activity against $S$. pyogenes, as well as adherence to KB or other cells. This leads us to more research in this sense, with the objective of selecting the best strains with high inhibitory capacity of GAS, as well as adherence to KB or oral cells for future tests of colonization in vivo with vehicles different from those that have been studied so far. 


\section{ACKNOWLEDGEMENTS}

The authors acknowledge funding from FAPESP - Processo 07/55377-0 - PIPE. We also thank the donation of KB cells by Dr. Marcia Pinto Alves Mayer, University of São Paulo, Brazil, as well as your suggestions for this work

\section{REFERENCES}

1. McCarthy C, Snyder ML, Parker RB. The indigenous oral flora of man. I. The newborn to the 1-year-old infants. Arch Oral Biol. 1965 Jan-Feb;10(1):61-70. http://dx.doi.org/10.1016/0003-9969(65)90058-0. PMid:14262161.

2. Carlsson J, Grahnén H, Jonsson G, Wikner S. Early stablisment of Streptococcus salivarius in the mouth of infants. J Dent Res. 1970 Mar-Apr;49(2):415-8. http://dx.doi.org/10.1177/00220345700490023601. PMid:5264606.

3. Tagg JR, Bannister LV. "Fingerprint" beta-haemolytic streptococci by their production of and sensitivity to bacteriocin-like inhibitors. J Med Microbiol. 1979 Nov;12(4):397-411. http://dx.doi.org/10.1099/00222615-12-4-397. PMid: 41951.

4. Fantinato V, Jorge AOC, Shimizu MT. Production of bacteriocin-like inhibitory substances (BLIS) by Streptococcus salivarius strains isolated from the tongue and throat of children with and without sore throat. Rev Microbiol. 1999 Dec;30(4):332-4. http://dx.doi.org/10.1590/S0001-37141999000400007.

5. Fantinato V, Zelante F. Streptococcus salivarius: detecção de cepas produtoras de substâncias semelhantes à bacteriocina contra bactérias bucais. Rev Microbiol São Paulo. 1990;22(1):49-54.

6. Roos K, Holm SE, Grahn E, Lind L. Alpha-streptococci as supplementary treatment of recurrent streptococcal tonsillitis: a randomized placebo-controlled study. Scand J Infect Dis. 1993;25(1):31-5. http://dx.doi.org/10.1080/00365549309169666. PMid:8460346.

7. Hardie JM, Bowden GH. Physiological classification of oral viridans streptococci. J Dent Res. 1976 Jan;55(1_suppl):A166-76. http://dx.doi.org/10.1177/002203457605500108011. PMid:1060638.

8. Igarashi T, Yano Y, Yamamoto A, Sasa R, Goto N. Identification of Streptococcus salivarius by PCR and DNA probe. Lett Appl Microbiol. 2001 Jun;32(6):394-7. http://dx.doi.org/10.1046/j.1472765X.2001.00928.x. PMid:11412350.

9. Wang H, Tan L, Liu J, Li Q, Pan Y, Zhong M. Effect of smokers'sera on Porphyromonas gingivalis internalizing KB cells and the expression of matrix metalloproteinase- $1,-9$ and tissue inhibitor of metalloproteinase-1. Zhonghua Kou Qiang Yi Xue Za Zhi. 2014 Jan;49(1):15-20. PMid:24697882.

10. Rose JE, Meyer DH, Fives-Taylor PM. Aae, an autotransporter involved in adhesion of Actinobacillus actinomycetemcomitans to epithelial cells. Infect Immun. 2003 May;71(5):2384-93. http://dx.doi.org/10.1128/IAI.71.5.2384-2393.2003. PMid:12704108.

11. Lamont RJ, Chan A, Belton CM, Izutsu KT, Vasel D, Weinberg A. Porphyromonas gingivalis invasion of gingival epithelial cells. Infect Immun. 1995 Oct;63(10):3878-85. PMid:7558295.

12. Lamont RJ, Koo H, Hajishengallis G. The oral microbiota: dynamic communities and host interactions. Nat Rev Microbiol. 2018 Dec;16(12):745-59. http://dx.doi.org/10.1038/s41579-018-0089-x. PMid:30301974.

13. Skovbjerg S, Roos K, Holm SE, Grahn Håkansson E, Nowrouzian F, Ivarsson M, et al. Spray bacteriotherapy decreases middle ear fluid in children with secretory otitis media. Arch Dis Child. 2009 Feb;94(2):92-8. http://dx.doi.org/10.1136/adc.2008.137414. PMid:18713796.

14. Mira A, Simon-Soro A, Curtis MA. Role of microbial communities in the pathogenesis of periodontal diseases and caries. J Clin Periodontol. 2017 Mar;44(Suppl 18):S23-38. http://dx.doi.org/10.1111/jcpe.12671. PMid:28266108. 
15. Florey HW. The use of micro-organisms for therapeutic purposes. Yale J Biol Med. 1946 Oct;19(1):10117. PMid:20275724.

16. Wescombe PA, Heng NC, Burton JP, Chilcott CN, Tagg JR. Streptococcal bacteriocins and the case for Streptococcus salivarius as model oral probiotics. Future Microbiol. 2009 Sep;4(7):819-35. http://dx.doi.org/10.2217/fmb.09.61. PMid:19722837.

17. Guglielmetti S, Taverniti V, Minuzzo M, Arioli S, Stuknyte M, Karp M, et al. Oral bacteria as potential probiotics for the pharyngeal mucosa. Appl Environ Microbiol. 2010 Jun;76(12):3948-58. http://dx.doi.org/10.1128/AEM.00109-10. PMid:20418429.

18. Burton JP, Cowley S, Simon RR, McKinney J, Wescombe PA, Tagg JR. Evaluation of safety and human tolerance of the oral probiotic Streptococcus salivarius K12: a randomized, placebo-controlled, doubleblind study. Food Chem Toxicol. 2011 Sep;49(9):2356-64. http://dx.doi.org/10.1016/j.fct.2011.06.038. PMid:21722694.

19. Di Pierro F, Colombo M, Giuliani MG, Danza ML, Basile I, Bollani T, et al. Effect of administration of Streptococcus salivarius $\mathrm{K} 12$ on the occurrence of streptococcal pharyngo-tonsillitis, scarlet fever and acute otitis media in 3 years old children. Eur Rev Med Pharmacol Sci. 2016 Nov;20(21):4601-6. PMid:27874935.

20. Di Pierro F, Risso P, Poggi E, Timitilli A, Bolloli S, Bruno M, et al. Use of Streptococcus salivarius K12 to reduce the incidence of pharyngo-tonsillitis and acute otitis media in children: a retrospective analysis in not-recurrent pediatric subjects. Minerva Pediatr. 2018 Jun;70(3):240-5. http://dx.doi.org/10.23736/S0026-4946.18.05182-4. PMid:29322750.

\section{CONFLICTS OF INTERESTS}

The authors declare no conflicts of interest.

\section{*CORRESPONDING AUTHOR}

Vera Fantinato, UNESP - Universidade Estadual Paulista, Instituto de Ciência e Tecnologia, Rua Geraldo Oliveira dos Anjos, 83, Esplanada do Sol, 12244-780 São José dos Campos - SP, Brasil, e- mail: biosim.bac@bol.com.br

Received: March 18, 2019

Accepted: July 11, 2019 